\title{
SELECTION OF FUSIBLE INTERLINING IN APPAREL INDUSTRY
}

\author{
Sashka Golomeova Longurova', Goran Demboski ${ }^{2}$, Sonja Jordeva', \\ Silvana Zezova', Vangja D. Kuzmanoska', Marija Kertakova', Kiro Mojsov'
}

1 Faculty of Technology, University "Goce Delcev" - Shtip,

Naučni rad

Krste Misirkov 10-A, Shtip, N. Macedonia

UDC: 687.053.665:677.074.33

* e-mail: saska.golomeova@ugd.edu.mk

doi: $10.5937 /$ tekstind1904004G

2 Faculty of Technology and Metallurgy, University "St. Kiril and Metodij"- Skopje

\begin{abstract}
The purpose of this paper was to select a fusible interlining in the production of men's shirts. The selection was based on bonding strength between the fabric and the interlining as a key property that defines the quality of the fusible interlining. The bonding strength was examined after fusing process and after five cycles of laundering. The fabric was fused with three fusible interlinings from different manufacturers and with different properties.
\end{abstract}

Key words: fusible interlining, bonding strength, orthogonal array.

\section{SELEKCIJA TERMOPLASTIČNE MEĐUPOSTAVE U INDUSTRIJI ODEĆE}

Apstrakt: Cilj ovog rada je selekcija termoplastične međupostave u proizvodnji muških košulja. Selekcija se zasniva na jačinu spoja između tkanine i međupostave kao ključne karakteristike koja određuje kvalitet termoplastične međupostave. Jačina spoja ispitivana je nakon postupka fiksiranja i nakon pet ciklusa pranja. Za termofiksiranje tkanine korišćene su tri različite međupostave, različitih proizvođača i različitih karakteristika.

Ključne reči: Termoplastična međupostava, jačina spoja, ortogonalni niz.

\section{INTRODUCTION}

Fusible interlinings are auxiliary materials in apparel production and they are very important for essential apparel quality. Fusible interlinings reinforce the fabric, improve the formability and tactile properties of outer fabric, and give a beautiful silhouette of the apparel $[1,2,3]$. With the fusing process, fusible interlining is bonded to the outer fabric by thermoplastic resin and produces a structure called laminate [4]. The bonding strength between the interlining and the fabric is very important for apparel quality because consumers want to keep the shape of apparel during wearing and after repeated laundering. During the wearing and laundering, apparel is exposed to mechanical stress and may cause delamination of the fusible interlining, which may impair the aesthetic appearance of the fused parts of the apparel. The bonding strength between the fusible interlining and outer fabric is essential for obtaining a laminate that will stand the process of laundering and dry cleaning. Although the minimum bond strength is not specified in the standards for bonding strength testing, in the literature and from practical experience, data can be found that the bond strength should be at least $10 \mathrm{~N}$ $/ 5 \mathrm{~cm}$ or $200 \mathrm{cN} / \mathrm{cm}$ [5]. Factors which have influence on the bonding strength of the laminate are fusible interlining and the parameters of fusing process, pressure, temperature and time. 


\section{EXPERIMENT}

In this paper, bonding strength was investigated between one fabric intended for men's shirts and three different fusible interlinings. The structural characteristics of the fabric and fusible interlinings are given in Table 1 and in Table 2, appropriate.

Table 1: Specification of fabric

\begin{tabular}{|c|c|}
\hline Raw material & $100 \%$ cotton \\
\hline Weight, $\mathrm{g} / \mathrm{m}^{2}$ & 125 \\
\hline Warp density, $\mathrm{cm}^{-1}$ & 56 \\
\hline Weft density, $\mathrm{cm}^{-1}$ & 38 \\
\hline
\end{tabular}

Table 4: Factors and levels

\begin{tabular}{|l|c|c|c|}
\hline \multicolumn{1}{|c|}{} & \multicolumn{3}{|c|}{ Levels } \\
\hline Factors & I & II & III \\
\hline $\begin{array}{l}\text { Fusing } \\
\text { interlining(A) }\end{array}$ & Freudenberg & Wendler & Staflex \\
\hline Temperature (B) & $150^{\circ} \mathrm{C}$ & $160^{\circ} \mathrm{C}$ & $170^{\circ} \mathrm{C}$ \\
\hline Pressure (C) & $1 \mathrm{bar}$ & $2 \mathrm{bar}$ & $3 \mathrm{bar}$ \\
\hline
\end{tabular}

Table 2: Specification of fusible interlinings

\begin{tabular}{|c|c|c|c|c|}
\hline \multirow{2}{*}{} & \multicolumn{2}{|c|}{ Fusible interlining } \\
\cline { 2 - 4 } & Weight, $\mathrm{g} / \mathrm{m}^{2}$ & Freudenberg & 100 & Staflex \\
\hline \multirow{3}{*}{ Composition } & Substrate & $100 \%$ cotton, woven & $100 \%$ cotton, woven & $100 \%$ cotton, woven \\
\cline { 2 - 5 } & Thermoplastic resin & PEHD, micro dots & PEHD, micro dots & PEHD, micro dots \\
\hline \multirow{3}{*}{$\begin{array}{c}\text { Fusing } \\
\text { parameters }\end{array}$} & $\mathrm{T}^{\circ}{ }^{\circ} \mathrm{C}$ & $143-166$ & $160-165$ & $150-170$ \\
\cline { 2 - 5 } & $\mathrm{P}$, bar & $0,8-3$ & $2-3$ & $1,8-2,5$ \\
\hline \multirow{2}{*}{ Care } & $\mathrm{t}, \mathrm{s}$ & $12-18$ & $12-18$ & $12-17$ \\
\cline { 2 - 5 } & $\mathrm{T}_{\text {max laundering, }}{ }^{\circ}{ }^{\circ} \mathrm{C}$ & 95 & 95 & 95 \\
\hline
\end{tabular}

Using orthogonal array $\mathrm{L}_{9}\left(3^{4}\right)$ the experiment plan was made, as shown in Table 3 . The experiments were carried out with 4 factors (A- fusing interlining; B- Temperature, $\mathrm{C}$ - pressure, D-time) at 3 levels, as shown in Table 4. Selection of the levels is based on the interlining fusing parameters specifications. The experiment layout using an " $\mathrm{L}_{9}$ " orthogonal array in Table 5 is shown.

Table 3: " $\mathrm{L}_{9}\left(3^{4}\right)$ " orthogonal array

\begin{tabular}{|l|l|l|l|l|}
\hline \multicolumn{5}{|c|}{ Factors } \\
\hline & A & B & C & D \\
\hline $\mathbf{1}$ & 1 & 1 & 1 & 1 \\
\hline $\mathbf{2}$ & 1 & 2 & 2 & 2 \\
\hline $\mathbf{3}$ & 1 & 3 & 3 & 3 \\
\hline $\mathbf{4}$ & 2 & 1 & 2 & 3 \\
\hline $\mathbf{5}$ & 2 & 2 & 3 & 1 \\
\hline $\mathbf{6}$ & 2 & 3 & 1 & 2 \\
\hline $\mathbf{7}$ & 3 & 1 & 3 & 2 \\
\hline $\mathbf{8}$ & 3 & 2 & 1 & 3 \\
\hline $\mathbf{9}$ & 3 & 3 & 2 & 1 \\
\hline \multicolumn{7}{|c|}{$\mathrm{L}_{9}\left(3^{4}\right)$} \\
\hline
\end{tabular}

Table 5: Experiment layout using an " $\mathrm{L}_{9}$ " orthogonal array table

\begin{tabular}{|c|c|c|c|c|}
\hline \multirow{2}{*}{ Exp.no } & \multicolumn{4}{|c|}{ Factor and level } \\
\hline & A & B & C & D \\
\hline 1 & Freudenberg & 150 & 1 & 12 \\
\hline 2 & Freudenberg & 160 & 2 & 15 \\
\hline 3 & Freudenberg & 170 & 3 & 18 \\
\hline 4 & Wendler & 150 & 2 & 18 \\
\hline 5 & Wendler & 160 & 3 & 12 \\
\hline 6 & Wendler & 170 & 1 & 15 \\
\hline 7 & Staflex & 150 & 3 & 15 \\
\hline 8 & Staflex & 160 & 1 & 18 \\
\hline 9 & Staflex & 170 & 2 & 12 \\
\hline
\end{tabular}

The three types of fusible interlinings were taken as levels of the factor $A$ - fusible interlining. At the Level 1 is interlining produced by Wendler, Germany, level 2 interlining produced by Staflex, Spain and 
level 3 is interlining produced by Freudenberg, Germany. The fusing process was carried out in factory conditions, on continuous fusing press type Gygli. Six samples were fused at each fusing conditions. Half of the samples, after fusing were exposed to five cycles of laundering and drying according the conditions in given in the ASTM D 2724 standard. After the fifth cycle, the samples were placed in a flat position on a flat surface and hand-ironed at $150^{\circ} \mathrm{C}$. During ironing no extra pressure was applied except the mass of the iron itself. The bonding strength of the fused laminate was tested on tensile testing machine Tinius Olsen HT45, in accordance with the ASTM D 2724 standard [7].

\section{RESULTS AND DISCUSSION}

The obtained results for bonding strength investigated after fusing process and after five cycles of laundering are given in Figure 1. The results given on the diagram calculate average values from the three measured values. According to the results, the highest bonding strength indicates the "Freudenberg" interlining, followed by "Staflex" interlining, while the lowest bonding strength indicates interlining produced by "Wendler". Compared to the minimum bonding strength of $200 \mathrm{cN} / \mathrm{cm}$, generally laminates with interlinings "Freudenberg" and "Staflex", have required bonding strength. The "Wendler" laminate, in all cases shows lower strength than $200 \mathrm{cN} / \mathrm{cm}$.

The "Freudenberg" laminate, for all combinations of parameters, after fusing process as after laundering process, has a higher values of bonding strength between fabric and interlining than the minimum strength of $200 \mathrm{cN} / \mathrm{m}$. The bonding strength of this laminate increases with the fusing parameters (temperature, pressure and time) increasing. Comparison of the values of the bonding strength after fusing and after 5 cycles of laundering indicates that the bonding strength after five cycles of laundering is higher than the strength after fusing, for all combination of parameters. According to the literature after laundering, the bonding strength decreases, but after ironing, as in our case, the strength may increase [6]. After ironing, the increasing of bonding strength is the result of the consolidation of the thermoplastic resin due to the effect of temperature and the pressure in the ironing process.

In the both cases of examination, after fusing process and after laundering process, for all combinations of fusing parameters, the "Wendler" laminate has lower bonding strength values than the minimum strength of $200 \mathrm{cN} / \mathrm{cm}$. The results of samples tested after fusing process, showed that the bonding strength increases with the rising of the temperature.
The obtained results show that the bonding strength after five cycles of laundering is lower than the bonding strength after fusing process, for all combinations of parameters.

The "Staflex" laminate, for all combinations of parameters, has a higher bonding strength than $200 \mathrm{cN}$ $/ \mathrm{cm}$ for samples tested after the fusing process. After five cycles of laundering, the value of bonding strength is slightly below $200 \mathrm{cN} / \mathrm{cm}$ except for the sample fused at the highest temperature of $170^{\circ} \mathrm{C}$. With rising of the temperature, the bonding strength slightly decreases in the group of samples tested after fusing. In the group of samples examined after laundering happens the opposite, the bonding strength increases with raising of the temperature.

In general, the comparison of the results of the bonding strength after fusing and after five cycles laundering indicates that the bonding strength decreases after laundering.

In the Figure 2 standard deviation of bonding strength for three types of fusible interlinings at all fusing parameters are shown.

From Figure 2, can be seen that the standard deviation of the bonding strength for the "Freudenberg" laminate is significantly changed by fusing parameters variation. In general, "Freudenberg" interlining shows that with increasing of the temperature the standard deviation increases for all samples, except for samples fused at temperature $170^{\circ} \mathrm{C}$ and tested after the fusing process. Here, for the highest fusing temperature $170^{\circ} \mathrm{C}$ the standard deviation is slightly lower than that of temperature $160^{\circ} \mathrm{C}$. From Figure 1 we have seen that at higher temperature the bonding strength is higher, but it can be noticed that the standard deviation, i.e. the coefficient of variation is increased, which must be taken into account when the optimal fusing parameters are being chosen.

The standard deviation of bonding strength of the fabric and interlining in the "Wendler" laminate doesn't show any trend in the magnitude under different fusing conditions. In the group of samples tested after fusing process, the sample fused at the lower temperature $\left(150^{\circ} \mathrm{C}\right)$ shows the lower standard deviation of the bonding strength than at the higher fusing temperatures. Samples tested after five cycles of laundering generally show higher standard deviation than samples examined after fusing process; higher at temperatures of $150^{\circ} \mathrm{C}$ and $170^{\circ} \mathrm{C}$ and lower at the temperature of $160^{\circ} \mathrm{C}$.

Standard deviation of bonding strength in the "Staflex" laminate increases with fusing temperature increasing for all examined samples (Figure 2). Sam- 


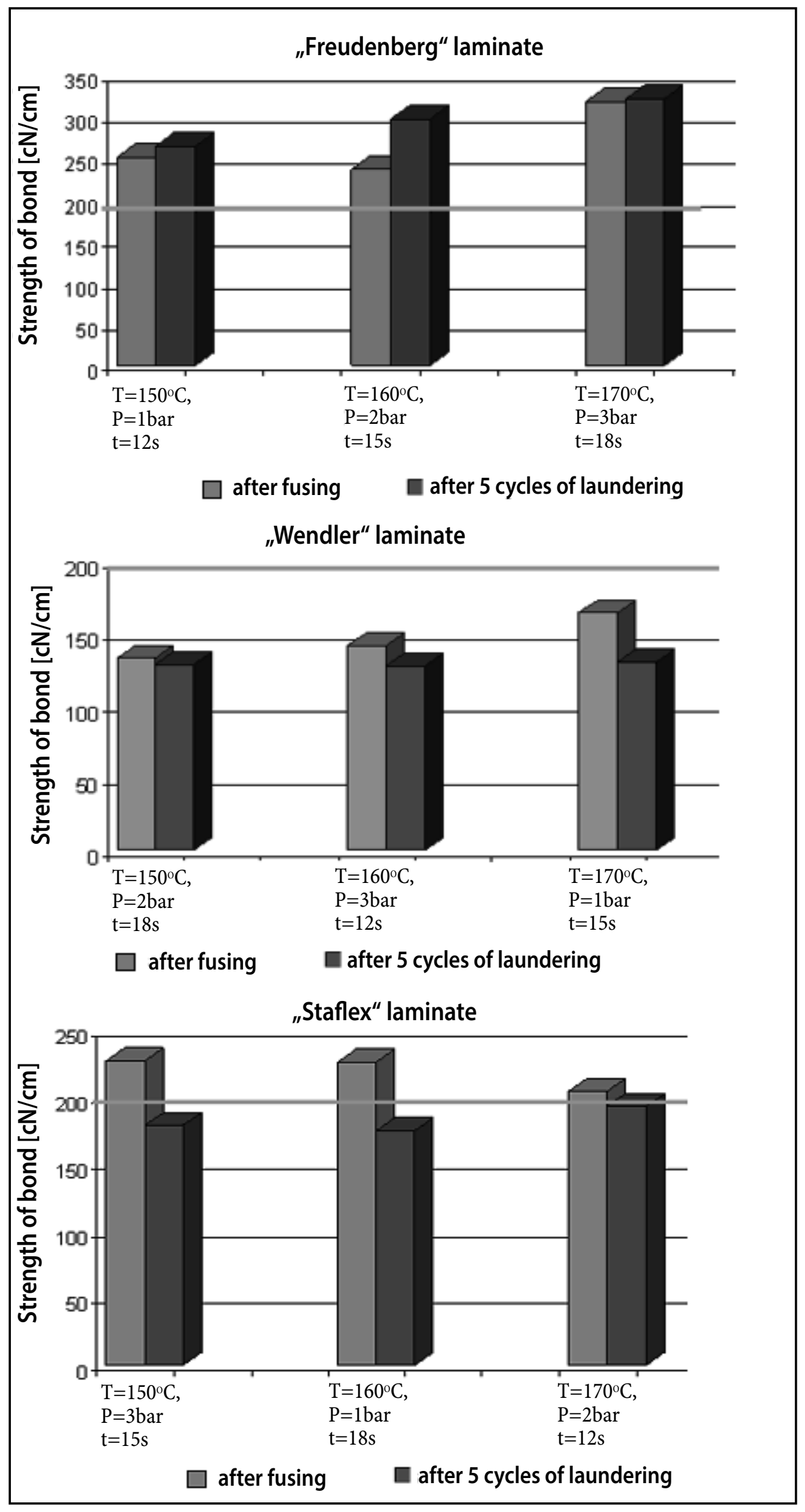

Figure1: Bonding strength of the laminate after fusing and after five cycle of laundering 

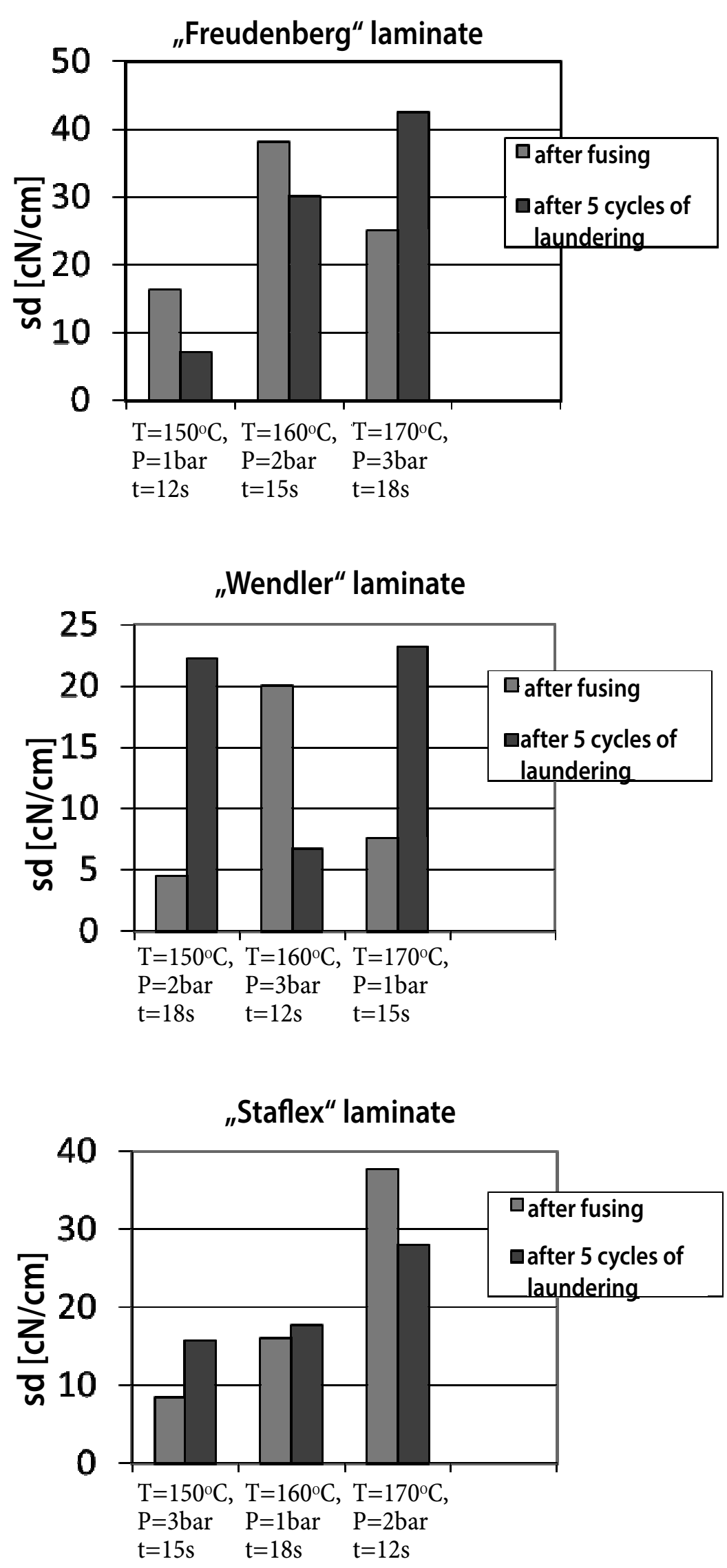

Figure 2: Standard deviation of bonding strength for all applied fusing parameters 
ples tested after laundering, fused at temperatures $150^{\circ} \mathrm{C}$ and $160^{\circ} \mathrm{C}$, show higher standard deviation of bonding strength than the samples tested after fusing process. In the case of this interlining, at the highest temperature the highest bonding strength is not obtained (Figure 1) which may suggest that it is more advantageous to use a lower temperature in terms of higher bonding strength, lower standard deviation and energy savings.

In consideration of the information given in the technical specification of interlinings, comparison of the obtained results of bonding strengths for different fusible interlinings leaves us some doubts. If we remind on table 2 with the recommended fusing parameters for the interlinings, it is noted that interlining by the manufacturer "Freudenberg" has the smallest weight $\left(80 \mathrm{~g} / \mathrm{m}^{2}\right)$, and consequently (assuming that the participation of the thermoplastic resin is approximately equal for all interlinings) the smallest amount of thermoplastic resin. However, this fusible interlining shows the higher bonding strength. Next, it is "Staflex" interlining which has highest weight $\left(110 \mathrm{~g} / \mathrm{m}^{2}\right)$ and the last is "Wendler" interlining with a weight of $100 \mathrm{~g} / \mathrm{m}^{2}$. A possible explanation for the higher bonding strength of the "Freudenberg" laminate may be in the range of recommended fusing temperatures in the interlining specification (table 2) given by the manufacturer. Compared to other interlinings, the temperature range recommended by this manufacturer $\left(143-166^{\circ} \mathrm{C}\right)$ is quite wide $\left(\Delta \mathrm{T}=23^{\circ} \mathrm{C}\right)$, and the initial fusing temperature is also lower (143 $\left.{ }^{\circ} \mathrm{C}\right)$. Also, the fusing temperature recommended by this manufacturer is from 0.8 to $3 \mathrm{bar}(\Delta \mathrm{P}=2.2 \mathrm{bar})$, which is quite low initial pressure and widest fusing pressure range compared to other interlinings. The comparison of these parameters with the fusing parameters applied in the experiment (table 4), shows that especially at the third level of the experiment (temperature of $170^{\circ} \mathrm{C}$ and pressure of 3 bar) where the highest bonding strength were achieved, fusing temperature and pressure which are much higher than initial ((temperature of $143^{\circ} \mathrm{C}$ and pressure of $0.8 \mathrm{bar}$ ) were used. Consequently, in this case it is possible extremely high mobility of the thermoplastic resin and improved penetration of the resin into the substrate and the base material to achieve due to the combination of higher temperature and higher pressure.

From the process economics point of view, lower levels of fusing parameters $\left(\mathrm{T}=150^{\circ} \mathrm{C}, \mathrm{P}=1 \mathrm{bar}, \mathrm{t}\right.$ $=12 \mathrm{~s}$ or $\mathrm{T}=160^{\circ} \mathrm{C}, 2$ bar, $\mathrm{t}=15 \mathrm{~s}$ ) can be taken as optimal fusing parameters for the "Freudenberg" interlining because the bonding strength under these conditions after the fusing process and after laundering is acceptable and the standard deviation is lower.

The interlining "Wendler", which creates laminate with the lowest bonding strength, has the lowest fusing temperature range $\left(160-165^{\circ} \mathrm{C}\right)$ recommended by the manufacturer. It could be thought that getting out of the narrow temperature range is a possible reason for very low bonding strength. Although, the fusing process was carried out with temperature of $160^{\circ} \mathrm{C}$ and pressure and time that completely overlap with recommended parameters from the specification, the laminate with this interlining has the lowest bonding strength compared to other fusible interlinings. The reason for this may be the low quality of thermoplastic resin, for which at the time of order and through the information available in the technical specifications no more detailed information can be found. In order to investigate the quality of the thermoplastic resin it is necessary to carry out tests which are not within the scope of the technical equipment of the apparel manufacturer.

\section{CONCLUSION}

In this study, a selection of a fusible interlining in the production of men's shirts was made. From the obtained results we can conclude that:

1. Only "Freudenberg" interlining creates a laminate with a bonding strength higher than $200 \mathrm{cN} / \mathrm{cm}$ in both cases, after fusing process and after five cycles of laundering. This result was obtained for all applied combinations of fusing parameters.

2. Fusing parameters in the specification of the "Freudenberg" interlining, temperature $\left(143^{\circ} \mathrm{C}\right)$ and pressure $(0,8 \mathrm{bar})$, are much more lower than the fusing parameters used in experiment and due to combination of the higher temperature and pressure, the viscosity of the thermoplastic resin decreases and penetration of the resin into the substrate and the outer fabric is improved.

3. When temperature and pressure are increasing, the bonding strength increases and standard variation increases, too.

4. For "Freudenberg" interlining fusing we suggest the lower fusing parameters $\left(T=150^{\circ} \mathrm{C}\right.$, $\mathrm{P}=1 \mathrm{bar}, \mathrm{t}=12 \mathrm{~s}$ ) because the bonding strength is acceptable and the standard deviation is the lowest. 


\section{REFERENCES}

[1] Cooklin, G. (1990). Fusing Technology, The Textile Institute, United Kingdom.

[2] Aldrich, W., Aldrich, J. (2007). Fabric, Form and Flat Pattern Cutting, Blackwell Publishing, United Kingdom.

[3] Cooklin, G., Hayes, S. G., McLoughlin, J.J. (2006). Introduction to clothing manufacture, Blackwell Publishing, Oxford, United Kingdom.

[4] Tyler, J. D. (2008). Carr and Lathman's Technology of Clothing Manufacture, Blackwell Publishing, Oxford
[5] Golomeova, S. (2011). Selection of supplier and quality of support materials in clothing production, master thesis, Faculty of Technology and Metallurgy, UKIM, Skopje.

[6] Дембоски Г., Манговска Б. (1993). Влијание на nараметрите на фронтално фиксирање врз јачината на лепење на основната ткаенина и меѓупоставата, Текстилство, 3-4,. 115.

[7] ASTM D 2724 (2003). Standard Test Method for Bonded, Fused and Laminated Apparel Fabric, ASTM International.

Rad primljen: 18.11.2019.

Rad prihvaćen: 9.12.2019. 